\title{
FLEXURE AND SHEAR BOND STRENGTH OF RED MUD - FLY ASH BASED GEOPOLYMER MORTARS
}

\author{
Smita Singh $^{1}$, H. P.Mahesh ${ }^{2}$, M. U. Aswath ${ }^{3}$, R. V. Ranganath ${ }^{4}$ \\ ${ }^{I}$ Assistant Professor, Dept. of Civil Engineering, Amrita school of Engineering, Amrita Vishwa Vidyapeetham, \\ Kasavanahalli, Carmelaram Post, Bangalore - 560 035, India \\ ${ }^{2}$ Senior Design Engineer, Larsen \& Tourbo Chennai, India \\ ${ }^{3}$ Professor \& Head, Dept. of Civil Engineering, Bangalore Institute of Technology, Bangalore, India \\ ${ }^{4}$ Professor, BMS College of Engineering, Bangalore, India
}

\begin{abstract}
Flexure and shear bond strength for masonry structures are important when they are subjected to in plane or out of plane loads. The paper focuses on the study of flexure and shear bond strength of masonry using red mud-fly ash based geopolymer mortar. Experiments have been carried out to determine the compressive strength of the geopolymer mortar. A total of 108 numbers, 70 mm size mortar cubes were casted by varying different percentages of red-mud (RM) along with fly-ash (FA) and silica fume (SF) of different molarities starting from $6 \mathrm{M}$ to $12 \mathrm{M}$ with an increment of $2 \mathrm{M}$ by keeping sodium hydroxide to sodium silicate solution ratio as 2.5. Mortar cubes of binder to fine aggregate ratio of 1:3, 1:4 and 1:6 have been casted and tested for compressive strength. For all the variationsin the composition of binder material, cubes casted with 10M alkali solution have themaximum strength. Hence mortar of molarity 10M was used in making triplets and prisms for shear and flexure bond test. By using $10 \%$ red mud, maximum shear and flexure bond strength obtained are 0.318 and $0.277 \mathrm{Mpa}$ and for 30\% red mud, $0.25 \mathrm{Mpa}$ and 0.215 Mpa. The compressive strength of the red mud - fly ash geopolymer mortar was found to be lesser than that of the cement mortar of same binder:aggregate ratio but it exhibited excellent bond strength.
\end{abstract}

Keywords redmud, fly ash, silica fume, alkaline liquids, compressive strength, masonry, shear, flexure $* * *$

\section{INTRODUCTION}

In the past few decades, geopolymer binders are being used as an eco-friendly alternative to cement. One of the key benefits in the use of geopolymer binders is that the toxic metal wastes are immobilized in the geopolymer matrix. This helps in stabilizing the huge volumes of industrial waste[11]. Red mud is one of such industrial wastes produced during the Bayer'sprocess of extraction of alumina from Bauxite. Generation of red mud worldwide is $\sim 70$ million tons with a global inventory of $\sim 2.7$ billion tons [6]. In India alone, the production of this Bauxite residue is $\sim 14$ million tons annually [8]. Although the main constituent element of red mud is iron, it also contains a good percentage of silica and alumina which are necessary for geopolymerisation.

Masonry erections are primarily subjected to compression loading; hence they are generally tested for compressive strength. In addition to compressive loading, masonry is frequently subjected to lateral loads, most significant being earthquake load and wind load. Hence, shear bond and flexure bond strength of masonry are the key parameters while designing for in plane and out of plane loads. Moreover, the failure of the masonry is usually by vertical splitting due to tensile stresses. Good bond strength provides resistance to the stresses resulting in increase of compressive strength of masonry. Hence, the bond strength characteristics of a mortar are equally important than its compressive strength. The present study is to investigate the possibility of using red mud in mortar synthesis and to study the flexure and shear bond strength of red mud based geopolymer mortar.

\section{REVIEW ON BOND STRENGTH OF MASONRY}

The bond strength between the mortar and the masonry unit depends on the mortar properties- mortar type (cement, polymer, geopolymer, soil or combination mortar), workability, drying shrinkage, properties of masonry unitstrength, moisture content of the unit while laying, surface texture and other factors such as curing conditions and bond enhancing methods adopted. Earlier it was believed that the failure of masonry in compression occurred due to deformation of either mortar or masonry unit. But the masonry structure may fail due to bed joint bond failure before the failure of masonry unit or the mortar due to poor bond strength [9]. The bond strength influences the masonry strength. Many studies on masonry bond strength have been undertaken in the past. Key findings of some of past studies on bond strength are discussed.

According to Venu Madhava et al., flexural bond strength of the masonry increases with the increase in the mortar strength and is independent of the masonry unit strength [17]. Surface characteristics of the unit greatly influence the adhesion between mortar and unit. Smooth surfaces coated with mortar have more bond strength than rough surfaces 
[12]. Smooth surfaces with many small pores can be uniformly coated with mortar compared to surfaces having few larger pores. Increasing the frog area of the brick leads to increase in the bond strength [9] Venkatarama Reddy et al. [15] studied the effect of sand grading on the characteristics of mortar and masonry. For bond behaviour, there is a decrease of $55 \%-60 \%$ in tensile bond strength of soil-cement block couplets as fineness modulus of sand varies from 3.21 to 1.72 . According to S. Andrejkovic ova et al.[1], the laboratory results can be misleading. The final characteristics of lime mortar depend of actual curing conditions and the curing techniques. Shear strength increases by $1.5-2$ times when the blocks are wet before laying [5].

Bond enhancing techniques such as fresh cement slurry coating and epoxy coating applied to the masonry unit greatly increases the adhesion [16], [13].

Brick to mortar bond strength can be improved by the addition of fibres. M. Zhu and D.D.L. Chung [19] studied the effect of adding carbon fibres to the mortar on bond strength. He found that the drying shrinkage of mortar decreases and the porosity increases on addition of carbon fibres. Highest strength was obtained at $0.5 \%$ of fibre by weight of the cement.

The combination mortars like cement-soil and cement lime mortar show better bond strength than conventional cement mortar [17]. These mortars can attain a flow up to $130 \%$ without segregation whereas in ordinary cement mortar maximum possible flow value is $107 \%$ [14].

Polymer and geopolymer mortars have good adhesion property. F. Gouny et al. carried out the feasibility study of metakaolin and silica fume based geopolymer mortar applied to bind earth brick and wood and found good adhesion property between them[2]. Shear and flexural bond strength of thin layer of polymer mortar were consistently greater than that of conventional cement mortar and increased with the increase in polymer content. Shear and flexure bond values were found to be almost equal [10].

\section{EXPERIMENTAL PROGRAM}

\subsection{Materials}

The materials used in this investigation are red mud, fly ash, silica fume, fine aggregate and alkaline liquids such as sodium silicate and sodium hydroxide. Ms HINDALCO, an aluminium plant in Belgaum, Karnataka supported the research by providing red mud. CASHUTEC, an agency to promote green building constructions in Raichur, Karnataka extended their help by making fly ash available for the study. The masonry units used for the test are locally available burnt bricks called table moulded bricks.

\subsection{Material Properties}

The chemical compositions of the source materials utilized in the investigation are listed in table 1 . Red mud particles are finer than the fly ash particle (fig. 1). They are characterized by unevenly shaped particles enclosed by finer particles forming agglomerate (fig. 2). The uneven shaped larger particles are likely to be hematite. The physical properties of red mud are listed in table 2. The maximum strength obtained in the lime reactivity test conducted on red mud is $0.65 \mathrm{Mpa}$. This indicates that the red mud particles are almost unreactive to lime and the silica present in the red mud is mostly in crystalline form.

Table moulded brick of size $220 \mathrm{~mm} \times 110 \mathrm{~mm} \times 70 \mathrm{~mm}$ is used for the bond strength test. The average water absorption of the bricks is found to be $14.026 \%$ by mass with a standard deviation of 0.3 . The average compressive strength of the bricks is $5.21 \mathrm{Mpa}$ with a standard deviation of 0.21 .

\subsection{Casting and Testing Procedure}

The mortar cubes were casted by varying different percentages of red-mud (RM) along with fly ash (FA) and silica fume (SF) of different molaritiesstarting from $6 \mathrm{M}$ to $12 \mathrm{M}$ with an increment of $2 \mathrm{M}$ by keeping sodium hydroxide to sodium silicate solution ratio as 2.5 . The mix design adopted was based on assuming the total water content in the solutions. Water content wasfixed at $230 \mathrm{litres} / \mathrm{m}^{3}$. The different variations of the binding materials adoptedwere red mud:fly ash:silica fume ratio in terms of percentage weight as 10:80:10, 30:60:10 and 50:40:10. Each of the above combination of binder was mixed with different proportions of fine aggregates, the ratio of binder to fine aggregate being $1: 3,1: 4$ and 1:6. 


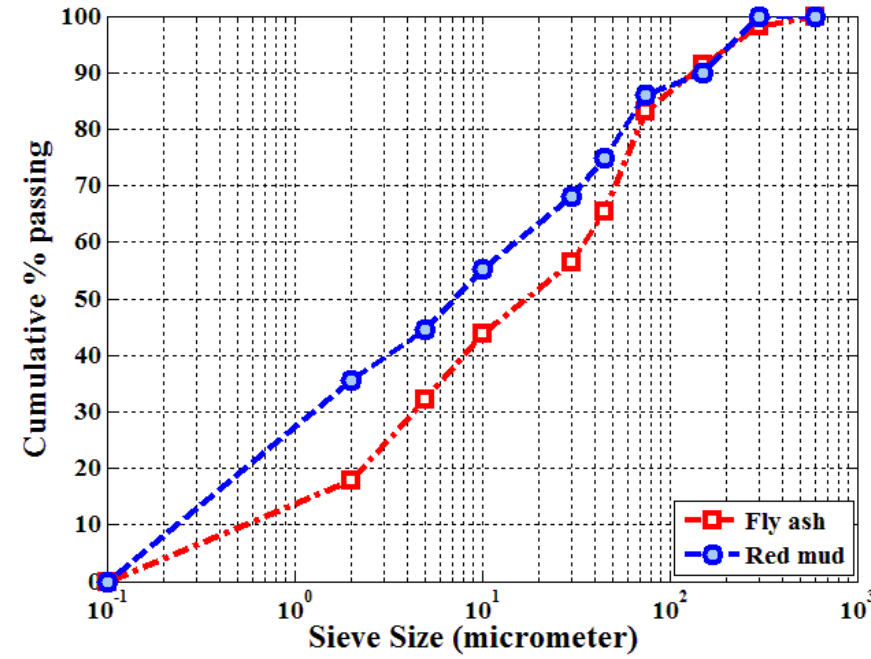

Fig.1 Grading Curve for red mud and fly ash
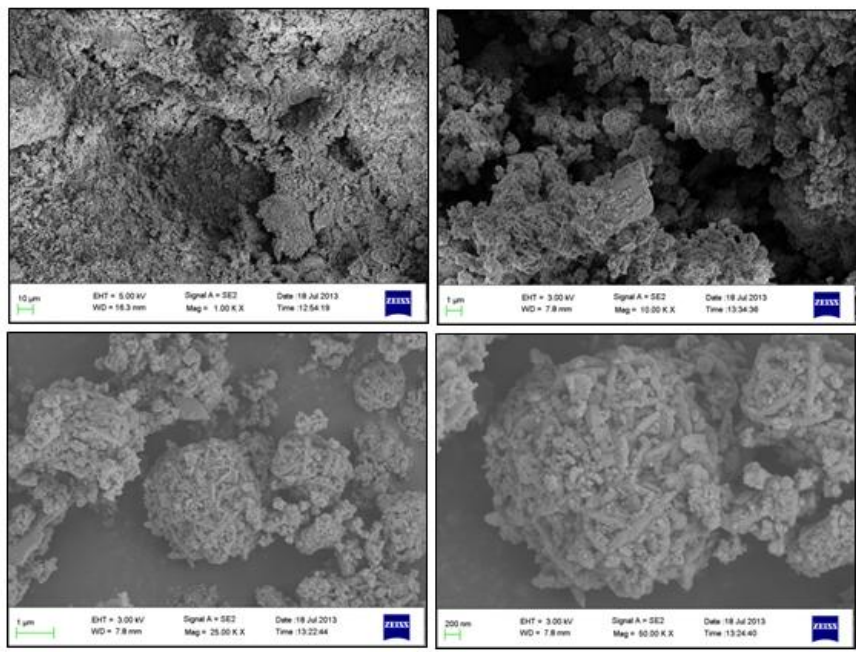

Fig. 2 SEM micrograph of red mud sample

Table 1Chemical composition of red mud, fly ash and microsilica

\begin{tabular}{|l|l|l|l|l|l|l|l|l|l|l|l|l|}
\hline \multirow{2}{*}{ Sample } & \multicolumn{1}{|l|}{ Metal oxide \% } \\
\cline { 2 - 14 } & $\mathbf{S i O}_{\mathbf{2}}$ & $\mathbf{A l}_{\mathbf{2}} \mathbf{O}_{\mathbf{3}}$ & $\mathbf{F e}_{\mathbf{2}} \mathbf{O}_{\mathbf{3}}$ & $\mathbf{C a O}$ & $\mathbf{K}_{\mathbf{2}} \mathbf{O}$ & $\mathbf{N a}_{\mathbf{2}} \mathbf{O}$ & $\mathbf{M g O}$ & $\mathbf{T i O}_{2}$ & $\mathbf{P}_{\mathbf{2}} \mathbf{O}_{\mathbf{5}}$ & $\mathbf{V}_{\mathbf{2}} \mathbf{O}_{\mathbf{5}}$ & $\mathbf{S O}_{3}$ & $\mathbf{L . O . I}$ \\
\hline RM & 9.93 & 18.1 & 42.9 & 2.3 & - & 5.58 & - & 9.03 & 0.35 & 0.31 & - & 10.5 \\
\hline FA & 61.54 & 25.37 & 6.73 & 3.1 & - & 0.97 & 0.73 & - & - & - & 0.62 & 0.39 \\
\hline MS & 99.32 & 0.2 & 0.09 & 0.1 & 0.02 & - & 0.04 & - & - & - & - & 0.01 \\
\hline
\end{tabular}

Table 2Properties of red mud

\begin{tabular}{|l|l|l|l|l|l|}
\hline Sample & \multirow{2}{*}{$\begin{array}{l}\text { Specific } \\
\text { gravity }\end{array}$} & Fineness & $\begin{array}{l}\text { Lime } \\
\text { reactivity } \\
\text { (Mpa) }\end{array}$ & $\begin{array}{l}\text { \% passing } \\
\text { through } \mathbf{7 5} \boldsymbol{\mu} \\
\text { sieve }\end{array}$ & PH \\
\hline RM 1 & 3.25 & 814 & 0.65 & 84 & 13 \\
\hline RM 2 & 3.2 & 735 & 0.53 & 86 & 13.1 \\
\hline RM 3 & 3.28 & 785 & 0.59 & 86 & 12.8 \\
\hline RM 4 & 3.11 & 728 & 0.57 & 86 & 12.8 \\
\hline RM 5 & 3.05 & 764 & 0.68 & 83 & 12.9 \\
\hline RM 6 & 3.09 & 873 & 0.65 & 85 & 12.8 \\
\hline RM 7 & 3.09 & 676 & 0.57 & 84 & 12.2 \\
\hline RM 8 & 3.11 & 732 & 0.58 & 85 & 13.2 \\
\hline
\end{tabular}

Geopolymer mortar cubes of size70 $\mathrm{mm} \times 70 \mathrm{~mm} \times 70 \mathrm{~mm}$ were casted.Thespecimens were cured inside the hot air curing chamber (HACC) at $60^{\circ} \mathrm{C}$ for 24 hours after 2-3 days of casting. It was observed that if the specimen, particularly the one with higher percentage of red mud is placed in the oven few hours after casting, there is noticeable bulging and distortion of the cube specimen. And there was a drastic change in the strength of the mortar cube. The bulging was due to the rapid evaporation of water or excess quantity of water used. Flocculation of clusters contained a large amount of water trapped within it just after the casting of cubes [18]. Rapid evaporation dislocated the red mud particles forming the clusters resulting in distortion and bulging. Weaker and porous areas are formed in the geopolymer matrix due to bulging which fails much before the expected load.Also, red mud geopolymerisation takes longer time, about 21 days to complete at ambient temperatures [7]and [4].

To determine the shear bond strength of the of brick mortar juncture, a three brick assembly was used. The bottom bricks of the triplet were rested on the bottom platform of the testing machine while the middle brick was not restrained against any vertical movement. The vertical load is applied to the middle brick so as to impart shear force to brick-mortar interface at the joint. The test setup is shown in fig.3. All the tests were performed without pre-compression load. 54 triplets were casted with different combinations keeping molarity constant at $10 \mathrm{M}$. The different combinations of the binding materials in terms of percentage weight were red mud:fly ash: silica fume ratio as 10:80:10, 30:60:10. The binder to fine aggregate proportion for each 
combination is $1: 3,1: 4$ and 1:6. The bricks used for triplets were pre-wetted before laying. The triplets were cured under HACC chamber for 24 hours at $60^{\circ} \mathrm{C}$ and tested after 7 days on $1000 \mathrm{kN}$ capacity Universal testing machine.

The bond wrench test as proposed by ASTM standard C1072 was altered to determine the flexure bond strength of the prisms. In the transformed test, the base of the prism was clamped rigidly to a concrete bed. Load was applied to the topmost brick by a pulley arrangement. The load created a moment which increased downwards and was maximum at the base of the prism. This ensured a flexure failure of the brick mortar joint near the base.
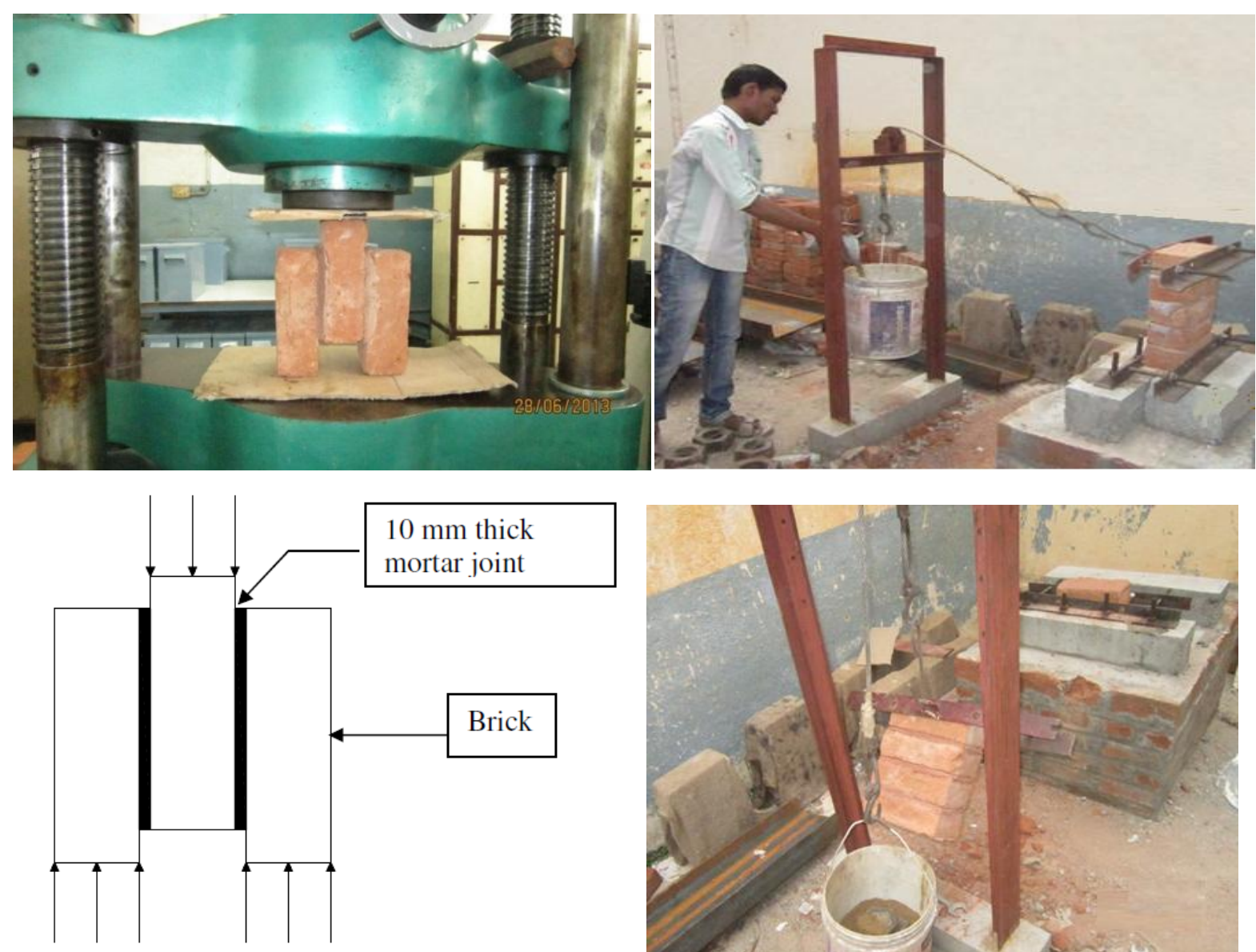

Fig. 3Triplet Test

\section{RESULTS AND DISCUSSIONS}

\subsection{Mortar}

All the mortar cubes were tested for compressive strength on the $7^{\text {th }}$ day from the day of casting. The results reveal that compressive strength of mortar cubes increased with the increase in molarity up to an optimum molarity. The optimum molarity was found to be $10 \mathrm{M}$ for all the three percentages of red mud variation and for all mortar compositions i.e. 1:3, 1:4 and 1:6 binder to fine aggregate ratio, table 3 and fig.5. Greater molarity hinders the leaching
According to the guidelines provided by the Indian standard code for structural use of unreinforced masonry (IS: 19051987), the minimum height of masonry prisms should be $40 \mathrm{~cm}$ high with height/thickness $(\mathrm{h} / \mathrm{t})$ ratio between 2 and 5 for determining the strength of masonry. Hence prisms of size $440 \mathrm{~mm} \times 230 \mathrm{~mm} \times 110 \mathrm{~mm}$ were cast to determine flexural strength. Prisms were cast in stack bond using moderate strength bricks with above mentioned combinations of three different proportions by keeping $10 \mathrm{M}$ as constant. In order to have a control over moisture content in brick at the time of laying, the bricks were immersed in water for a period of 15 minutes. Mortar joint thickness of $10 \mathrm{~mm}$ was maintained and was cured under HACC chamber for a period of 24 hours. These specimens were tested under modified bond wrench test (fig.4).

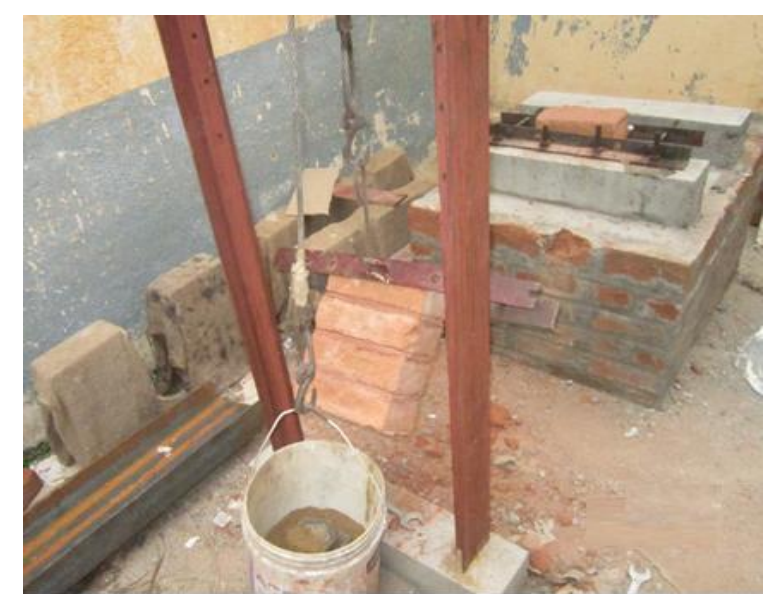

Fig. 4Modified bond wrench test

of aluminium and silicate ions, thus slowing the geopolymerisation process. Also higher concentration of $\mathrm{OH}$ - ions leads to early precipitation of aluminosilicate gelwhich hinders with the geopolymerisation process[3]. Thestrength of the mortar cubes varied from 1.39 Mpa to $4.48 \mathrm{Mpa}$. Except for a few data, the density of the cubes followed the almost the same pattern as the compressive strength, fig 6. Overall, the density of the red mud geopolymer mortar is found to be lesser than the normal cement mortar. 


\subsection{Shear and Flexure Bond}

The result of the triplet test for determining shear bond strength and modified wrench test for flexure bond strength is represented in table 4 and fig. 7. The results indicate good shear and flexure bond strength particularly for richer mortar. For mortar with binder:fine aggregate ratio of 1:3, change in mortar compressive strength is $19.2 \%$, shear bond strength is $21.3 \%$ and flexure bond strength is $22.4 \%$ when the red mud content in the binder changes from $10 \%$ to $30 \%$. For a leaner mortar with binder: fine aggregate ratio of 1:6, change in compressive strength of the mortar is $14.4 \%$, $24.9 \%$ for shear bond strength and $37.08 \%$ for flexure bond strength for the same variation of red mud.

The results are compared with some of the past studies on shear bond strength, table 5. Jonaitis et al.[5] performed a triplet test to find the shear bond strength of hollow calcium silicate block using $2 \mathrm{~mm}$ thick layer of MIRA 5010 glue as a mortar. The maximum shear bond strength of $0.22 \mathrm{Mpa}$ was obtained by him when he used the block of strength 19.71 Mpa and mortar strength of $12.56 \mathrm{Mpa}$. In another study by Venkatarama Reddy et al. [16], shear bond strength of 0.12 was obtained by using soil cement block of strength
5.09 Mpa and cement: sand: lime mortar of strength 3.42 Mpa. The strength was increased to 0.22 , when the test was performed using the same mortar but a block of 11.46 Mpa strength. By using bond enhancing technique, he was able to obtain shear bond strength of $0.83 \mathrm{Mpa}$, using the same mortar and block. In the present study, the maximum value of shear bond strength of $0.318 \mathrm{Mpa}$ was obtained without any bond enhancing technique by using brick of strength 5.04 Mpa and the mortar strength was 4.27 MPa.

Venu Madhava Rao et al.[17] carried out extensive research on flexure bond strength by using different types of masonry units and mortar. They were able to obtain flexure bond strength of $0.29 \mathrm{Mpa}$ with stabilized soil sand block of strength $9.1 \mathrm{Mpa}$ and cement sand mortar of strength 8.4 Mpa. Same flexure strength was obtained when he replaced the cement soil mortar with cement-soil-sand mortar of strength 3.8 Mpa. In the present investigation, almost same value of flexure bond strength $(0.28 \mathrm{Mpa})$ is obtained when the mortar compressive strength was $4.27 \mathrm{Mpa}$ and a much lesser masonry unit compressive strength of $5.04 \mathrm{Mpa}$ for $10 \%$ red mud.
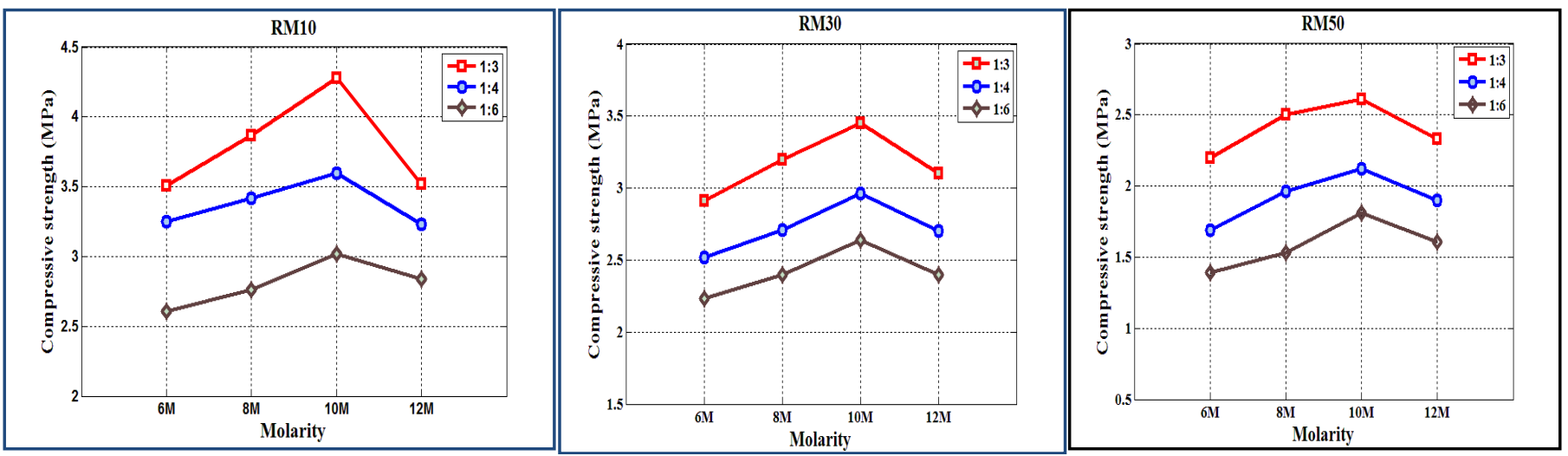

Fig. 5Effect of molarity on compressive strength
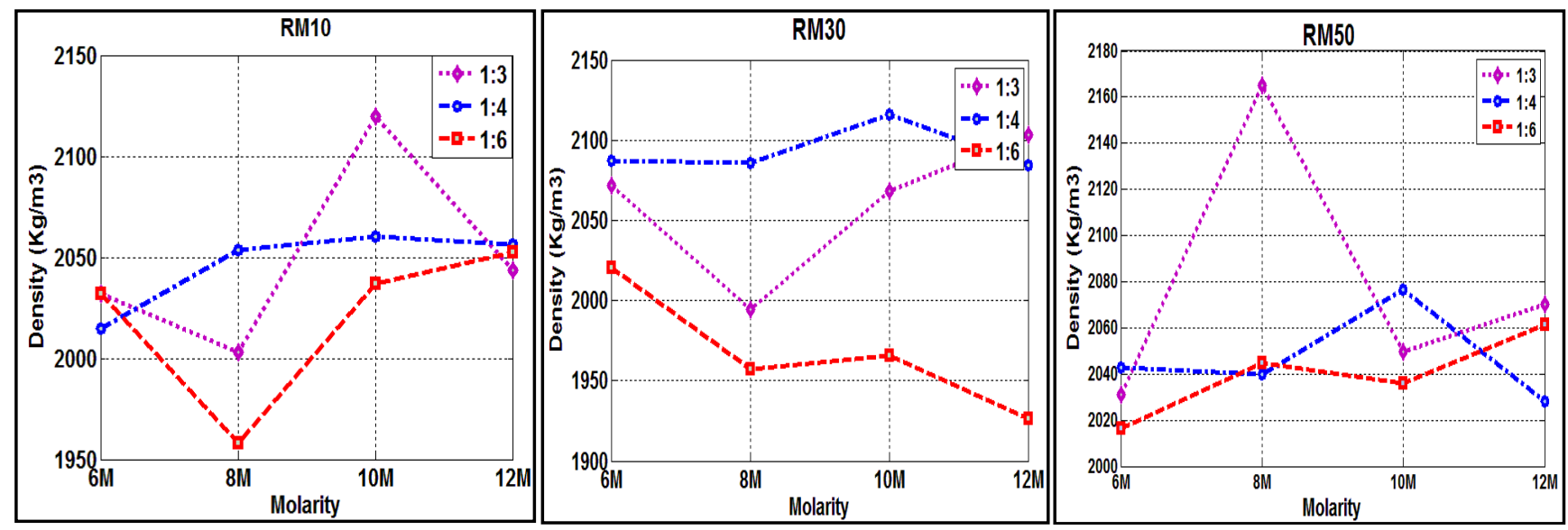

Fig. 6 Effect of molarity on density 
Table 3 Results of compressive strength test on mortar cubes

\begin{tabular}{|c|c|c|c|c|c|c|c|c|c|}
\hline \multicolumn{4}{|c|}{$10 \%$ Red Mud } & \multicolumn{3}{|c|}{$30 \%$ Red Mud } & \multicolumn{3}{|c|}{$50 \%$ Red Mud } \\
\hline Molarity & $\begin{array}{l}\text { Flow } \\
\text { mm }\end{array}$ & $\begin{array}{l}\text { Density } \\
\mathrm{kg} / \mathrm{m}^{3}\end{array}$ & $\begin{array}{l}\text { Comp } \\
\text { Strength } \\
N / \mathrm{mm}^{2}\end{array}$ & $\begin{array}{l}\text { Flow } \\
\text { mm }\end{array}$ & $\begin{array}{l}\text { Density } \\
\mathrm{kg} / \mathrm{m}^{3}\end{array}$ & $\begin{array}{l}\text { Comp } \\
\text { Strength } \\
\mathrm{N} / \mathrm{mm}^{2}\end{array}$ & $\begin{array}{l}\text { Flow } \\
\text { mm }\end{array}$ & $\begin{array}{l}\text { Density } \\
\mathrm{kg} / \mathrm{m}^{3}\end{array}$ & $\begin{array}{l}\text { Comp } \\
\text { Strength } \\
\text { N/mm }\end{array}$ \\
\hline \multicolumn{10}{|l|}{$1: 3$} \\
\hline $6 \mathrm{M}$ & 78 & 2,032 & 3.51 & 79 & 2,072 & 2.91 & 80 & 2,031 & 2.2 \\
\hline $8 \mathrm{M}$ & 75 & 2,003 & 3.87 & 74 & 1,994 & 3.2 & 77 & 2,165 & 2.49 \\
\hline $10 \mathrm{M}$ & 74 & 2,120 & 4.28 & 72 & 2,070 & 3.45 & 75 & 2,050 & 2.61 \\
\hline $12 \mathrm{M}$ & 72 & 2,044 & 3.52 & 69 & 2,103 & 3.1 & 72 & 2,070 & 2.32 \\
\hline \multicolumn{10}{|l|}{$1: 4$} \\
\hline $6 \mathrm{M}$ & 73 & 2,015 & 3.25 & 76 & 2,088 & 2.52 & 79 & 2,043 & 1.69 \\
\hline $8 \mathrm{M}$ & 71 & 2,053 & 3.42 & 74 & 2,086 & 2.71 & 76 & 2,040 & 1.96 \\
\hline $10 \mathrm{M}$ & 69 & 2,060 & 3.6 & 71 & 2,116 & 2.96 & 74 & 2,077 & 2.12 \\
\hline $12 \mathrm{M}$ & 70 & 2,056 & 3.23 & 70 & 2,085 & 2.7 & 71 & 2,028 & 1.9 \\
\hline \multicolumn{10}{|l|}{ 1:06 } \\
\hline $6 \mathrm{M}$ & 67 & 2,032 & 2.61 & 73 & 2,020 & 2.23 & 76 & 2,017 & 1.39 \\
\hline $8 \mathrm{M}$ & 65 & 1,958 & 2.76 & 71 & 1,928 & 2.4 & 73 & 2,045 & 1.53 \\
\hline $10 \mathrm{M}$ & 67 & 2,037 & 3.02 & 70 & 1,966 & 2.64 & 70 & 2,036 & 1.81 \\
\hline $12 \mathrm{M}$ & 69 & 2,053 & 2.84 & 70 & 1,926 & 2.4 & 70 & 2,061 & 1.61 \\
\hline
\end{tabular}

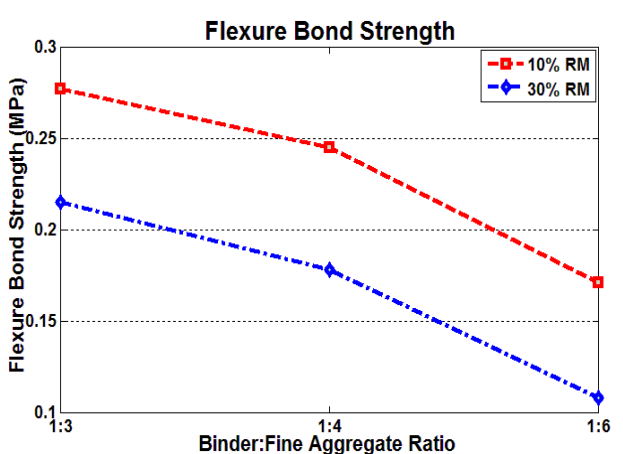

(a)

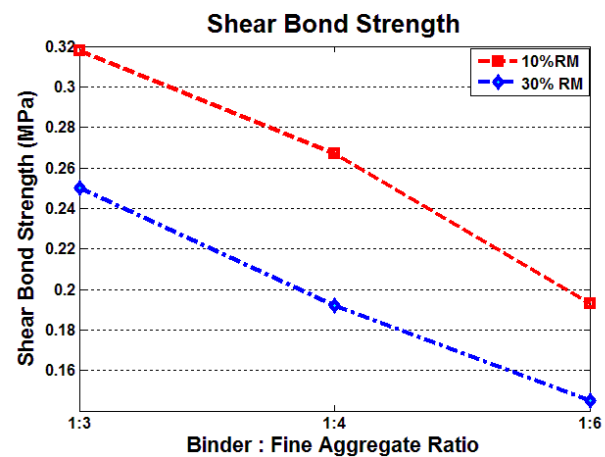

(b)

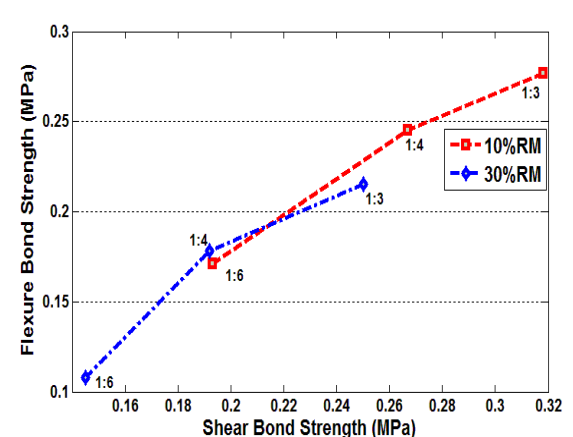

(c)

Fig. 7 Modified bond wrench test for $10 \%$ and $30 \%$ red mud a) flexure bond vs. binder: fine aggregate ratio b) shear bond vs. binder: fine aggregate ratio c) relationship between shear and flexure bond.

Table 4 Results of shear and flexure bond test

\begin{tabular}{|c|c|c|c|c|c|c|}
\hline \multirow{2}{*}{$\begin{array}{l}\text { Mortar Type } \\
\text { (Binder:Fine } \\
\text { Aggregate } \\
\text { Ratio) }\end{array}$} & \multirow{2}{*}{$\begin{array}{l}\text { Compressive } \\
\text { Strength of } \\
\text { Mortar } \\
\text { (Mpa) }\end{array}$} & \multirow{2}{*}{$\begin{array}{l}\text { Compressive } \\
\text { Strength of } \\
\text { Masonry unit } \\
\text { (Mpa) }\end{array}$} & \multicolumn{2}{|c|}{ Shear bond Strength } & \multicolumn{2}{|c|}{$\begin{array}{ll}\text { Flexure } & \text { bond } \\
\text { Strength } & \end{array}$} \\
\hline & & & $\begin{array}{l}\text { Mean } \\
\text { (Mpa) }\end{array}$ & $\begin{array}{l}\text { Standard } \\
\text { deviation } \\
\text { (Mpa) }\end{array}$ & $\begin{array}{l}\text { Mean } \\
\text { (Mpa) }\end{array}$ & $\begin{array}{l}\text { Standard } \\
\text { deviation } \\
\text { (Mpa) }\end{array}$ \\
\hline \multicolumn{7}{|c|}{ 10\% Red Mud } \\
\hline $1: 3$ & 4.27 & 5.04 & 0.318 & 0.017 & 0.277 & 0.060 \\
\hline $1: 4$ & 3.6 & 4.96 & 0.267 & 0.006 & 0.245 & 0.050 \\
\hline 1:6 & 3.02 & 5.34 & 0.193 & 0.007 & 0.171 & 0.036 \\
\hline \multicolumn{7}{|c|}{ 30\% Red Mud } \\
\hline $1: 3$ & 3.45 & 5.47 & 0.25 & 0.015 & 0.215 & 0.016 \\
\hline $1: 4$ & 2.96 & 5.14 & 0.192 & 0.009 & 0.178 & 0.012 \\
\hline 1:6 & 2.64 & 5.45 & 0.145 & 0.008 & 0.108 & 0.012 \\
\hline
\end{tabular}


Table 5 Results of shear and flexure bond test of some past studies

\begin{tabular}{|c|c|c|c|c|c|c|}
\hline Masonry Unit Type & $\begin{array}{l}\text { Masonry } \\
\text { Unit } \\
\text { Strength } \\
\text { (Mno) }\end{array}$ & Mortar Type & $\begin{array}{l}\text { Mortar } \\
\text { Strengt } \\
\text { h } \\
\text { (Mno) }\end{array}$ & $\begin{array}{l}\text { Characteris } \\
\text { tic shear } \\
\text { bond }\end{array}$ & $\begin{array}{l}\text { Flexur } \\
\text { e bond } \\
\text { strengt } \\
\text { h }\end{array}$ & $\begin{array}{l}\text { Referenc } \\
\text { e }\end{array}$ \\
\hline $\begin{array}{lcc}\text { Calcium } & \text { silicate } & \text { hollow } \\
\text { Blocks } & (180 \times 198 \times 340)\end{array}$ & 15.39 & \multirow{6}{*}{$\begin{array}{l}2 \mathrm{~mm} \text { thick layer } \\
\text { of MIRA } 5010 \\
\text { glue }\end{array}$} & 10.53 & 0.11 & - & [5] \\
\hline $\begin{array}{lr}\text { Calcium } & \text { silicate hollow } \\
\text { Blocks } & (240 \times 198 \times 340)\end{array}$ & 19.71 & & 12.56 & 0.22 & - & {$[5]$} \\
\hline $\begin{array}{lrr}\text { Calcium } & \text { silicate } \text { hollow } \\
\text { Blocks } & (180 \times 198 \times 340), \\
27.16 \% & \text { hollow, moistened } \\
\end{array}$ & 17.75 & & 8.41 & 0.15 & - & [5] \\
\hline $\begin{array}{lrr}\text { Calcium } & \text { silicate } \text { hollow } \\
\text { Blocks } & (240 \times 198 \times 340), \\
22.62 \% & \text { hollow, moistened } \\
\end{array}$ & 16.65 & & 8.41 & 0.12 & - & {$[5]$} \\
\hline $\begin{array}{lcr}\text { Calcium } & \text { silicate } & \text { hollow } \\
\text { Blocks }(150 \times 198 \times 340) & 13.9 \%\end{array}$ & 24.7 & & 24.7 & - & 0.084 & {$[5]$} \\
\hline $\begin{array}{lll}\text { Calcium silicate } & \text { hollow } \\
\text { Blocks (150x198x340), } & 13.9 \% \\
\text { hollow, moistened } & \text { before }\end{array}$ & 24.7 & & 7.59 & - & 0.178 & [5] \\
\hline \multirow{5}{*}{$\begin{array}{l}\text { Stabilised mud block } \\
(305 \times 143 \times 100)\end{array}$} & 4.6 & 1:4 (cement:sand) & 8.4 & - & 0.23 & {$[17]$} \\
\hline & 4.6 & 1:6 (cement:sand) & 3.6 & - & 0.1 & [17] \\
\hline & 4.6 & $1: 10$ & 0.9 & - & 0.02 & [17] \\
\hline & 4.6 & $\begin{array}{l}1: 1: 6 \\
\text { (cement:soil:sand) }\end{array}$ & 3.8 & - & 0.17 & [17] \\
\hline & 4.6 & $\begin{array}{l}1: 1: 10 \\
\text { (cement:lime:sand }\end{array}$ & 3.3 & - & 0.12 & [17] \\
\hline \multirow{5}{*}{$\begin{array}{l}\text { Stabilised soil sand block } \\
(229 \times 109 \times 70)\end{array}$} & 9.1 & 1:4 (cement:sand) & 8.4 & - & 0.29 & [17] \\
\hline & 9.1 & 1:6 (cement:sand) & 3.6 & - & 0.12 & {$[17]$} \\
\hline & 9.1 & $1: 10$ & 0.9 & - & 0.05 & {$[17]$} \\
\hline & 9.1 & $\begin{array}{l}1: 1: 6 \\
\text { (Cement:soil:sand }\end{array}$ & 3.8 & - & 0.29 & [17] \\
\hline & 9.1 & $\begin{array}{l}1: 1: 10 \\
\text { (Cement:lime:san }\end{array}$ & 3.3 & - & 0.17 & [17] \\
\hline \multirow[t]{5}{*}{ Burnt Brick (224x105x75) } & 56 & 1.4 (cement.sand) & 84 & - & 01 & {$[17]$} \\
\hline & 5.6 & 1:6 (cement:sand) & 3.6 & - & 0.08 & [17] \\
\hline & 5.6 & $1: 10$ & 0.9 & - & 0.05 & [17] \\
\hline & 5.6 & $\begin{array}{l}1: 1: 6 \\
\text { cement:soil:sand) }\end{array}$ & 3.8 & - & 0.11 & [17] \\
\hline & 5.6 & $\begin{array}{l}\text { 1:1:10 } \\
\text { (cement:lime:sand }\end{array}$ & 3.3 & - & 0.08 & [17] \\
\hline 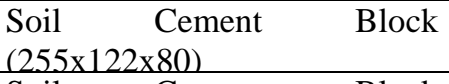 & 5.09 & $\begin{array}{l}1: 1: 6 \\
\text { (cement:lime:sand }\end{array}$ & 3.42 & 0.12 & - & {$[16]$} \\
\hline $\begin{array}{l}\text { Soil Cement } \begin{array}{l}\text { Block } \\
\text { (bond } \\
(255 \times 122 \times 80)\end{array} \\
\text { enhancing technique-fresh } \\
\text { cement slurry coating on the }\end{array}$ & 5.09 & $\begin{array}{l}\text { 1:1:6 } \\
\text { (cement:lime:sand } \\
\text { ) }\end{array}$ & 3.42 & 0.51 & - & {$[16]$} \\
\hline $\begin{array}{l}\text { Soil Cement } \\
(255 \times 122 \times 80) \text { epoxy } \\
\text { Block } \\
\text { on the plain block surfaces }\end{array}$ & 5.09 & $\begin{array}{l}\text { 1:1:6 } \\
\text { (cement:lime:sand } \\
\text { ) }\end{array}$ & 3.42 & 0.45 & - & [16] \\
\hline $\begin{array}{lll}\text { Soil Cement } & \text { Block } \\
(255 \times 122 \times 80) & \\
\end{array}$ & 11.46 & $\begin{array}{l}1: 1: 6 \\
\text { (cement:lime:sand }\end{array}$ & 3.42 & 0.22 & - & {$[16]$} \\
\hline $\begin{array}{l}\text { Soil Cement } \frac{\text { Block }}{2} \\
(255 \times 122 \times 80) \text { (fresh cement } \\
\text { slurry coating on the plain }\end{array}$ & 11.46 & $\begin{array}{l}1: 1: 6 \\
\text { (cement:lime:sand } \\
\text { ) }\end{array}$ & 3.42 & 0.83 & - & {$[16]$} \\
\hline $\begin{array}{l}\text { Soil Cement } \\
(255 \times 122 \times 80) \text { epoxy } \\
\text { on the plain } \\
\text { on block surfaces }\end{array}$ & 11.46 & $\begin{array}{l}\text { 1:1:6 } \\
\text { (cement:lime:sand } \\
\text { ) }\end{array}$ & 3.42 & 0.73 & - & {$[16]$} \\
\hline
\end{tabular}




\section{CONCLUSION}

Red mud consists very fine particles, approximately $30 \%$ are of the size of the clay (lesser than 2 micron). The XRD test shows the presence of hematite and various other aluminosilicate compounds, there is no trace of clay minerals. The uncalcined red mud used did not show much pozzolanic activity as evident from the lime reactivity test. This implies that the most of silica present in the red mud is nonreactive and is present in crystalline form. Red mud shows some pozzolanic activity at $600^{\circ} \mathrm{C}$ due to formation of poorly crystallized $\mathrm{Ca}_{2} \mathrm{SiO}_{4}$ resulting from the decomposition of amorphous aluminosilicates[7]. Since red mud is difficult to handle alone and has little pozzolanic activity, it was mixed with fly ash of varying percentages to synthesize the geopolymer mortar. Microsilica was used in the fixed quantity to maintain a suitable alumina to silica ratio for geopolymerisation. It was observed that the increase in molarity of sodium hydroxide increases the compressive strength of geopolymer mortar up to an optimum limit and then it started decreasing. The optimum molarity was found to be $10 \mathrm{M}$ for all percentages of red mud.

Red mud- fly ash geopolymer mortar exhibited remarkable bond strength properties as compared to cement sand mortar and other combination mortars. The cohesive and inherent stickiness of redmud particles helps the mortar to fill the gap fully and freely. to develop a stronger bond between the masonry units. Hence, red mud - fly ash mortar is an excellent alternative to many structural applications. Particularly its good bond strength makes it an excellent green alternative to be utilized for such masonry structures where better seismic resistance is required.

\section{REFERENCES}

[1] Andrejkovičová S, Velosa AL, Rocha F (2013) Air lime-metakaolin-sepiolite mortars for earth based walls Construction and Building Materials 44:133141.

doi:http://dx.doi.org/10.1016/j.conbuildmat.2013.03.0 08

[2] Gouny F, Fouchal F, Maillard P, Rossignol S (2012) A geopolymer mortar for wood and earth structures Construction and Building Materials 36:188-195 doi:http://dx.doi.org/10.1016/j.conbuildmat.2012.04.0 09

[3] He J, Jie Y, Zhang J, Yu Y, Zhang G (2013) Synthesis and characterization of red mud and rice husk ash-based geopolymer composites Cement and Concrete Composites 37:108-118 doi:http://dx.doi.org/10.1016/j.cemconcomp.2012.11. 010

[4] He J, Zhang J, Yu Y, Zhang G (2012) The strength and microstructure of two geopolymers derived from metakaolin and red mud-fly ash admixture: A comparative study Construction and Building Materials 30:80-91 doi:http://dx.doi.org/10.1016/j.conbuildmat.2011.12.0 11
[5] Jonaitis B, Marčiukaitis G, Valivonis J (2009) Analysis of the shear and flexural behaviour of masonry with hollow calcium silicate blocks Engineering Structures 31:827-833 doi:http://dx.doi.org/10.1016/j.engstruct.2009.01.001

[6] Klauber C, Gräfe M, Power G (2011) Bauxite residue issues: II. options for residue utilization Hydrometallurgy 108:11-32 doi:http://dx.doi.org/10.1016/j.hydromet.2011.02.007

[7] Liu X, Zhang N, Sun H, Zhang J, Li L (2011) Structural investigation relating to the cementitious activity of bauxite residue - Red mud Cement and Concrete Research 41:847-853 doi:http://dx.doi.org/10.1016/j.cemconres.2011.04.00 4

[8] Samal S, Ray AK, Bandopadhyay A (2013) Proposal for resources, utilization and processes of red mud in India - A review International Journal of Mineral Processing

118:43-55 doi:http://dx.doi.org/10.1016/j.minpro.2012.11.001

[9] Sarangapani G, Venkatarama Reddy B, Jagadish K (2005) Brick-Mortar Bond and Masonry Compressive Strength Journal of Materials in Civil Engineering 17:229-237

[10] Thamboo JA, Dhanasekar M, Yan C (2013) Flexural and shear bond characteristics of thin layer polymer cement mortared concrete masonry Construction and Building Materials 46:104-113 doi:http://dx.doi.org/10.1016/j.conbuildmat.2013.04.0 02

[11] Van Jaarsveld JGS, Van Deventer JSJ, Schwartzman A (1999) The potential use of geopolymeric materials to immobilise toxic metals: Part II. Material and leaching characteristics Minerals Engineering 12:7591 doi:http://dx.doi.org/10.1016/S08926875(98)00121-6

[12] Venkatarama Reddy B, Gupta A (2006) Tensile Bond Strength of Soil-Cement Block Masonry Couplets Using Cement-Soil Mortars Journal of Materials in Civil Engineering 18:36-45.

[13] Venkatarama Reddy B, Lal R, Nanjunda Rao K (2007) Enhancing Bond Strength and Characteristics of Soil-Cement Block Masonry Journal of Materials in Civil Engineering 19:164-172

[14] Venkatarama Reddy BV, Gupta A (2005) Characteristics of cement-soil mortars Materials and Structures 38:639-650

[15] Venkatarama Reddy BV, Gupta A (2008) Influence of sand grading on the characteristics of mortars and soil-cement block masonry Construction and Building Materials 22:1614-1623 doi:http://dx.doi.org/10.1016/j.conbuildmat.2007.06.0 14

[16] Venkatarama Reddy BV, Uday Vyas CV (2008) Influence of shear bond strength on compressive strength and stress-strain characteristics of masonry Materials and Structures 41:1697-1712

[17] Venu Madhava Rao K, Venkatarama Reddy BV, Jagadish KS (1996) Flexural bond strength of 
masonry using various blocks and mortars Materials and Structures 29:119-124

[18] Wang X, Qu Y-y, Hu W-w, Chen J, Zhao X-y, Wu M (2008) Particle characteristics and rheological constitutive relations of high concentration red mud Journal of China University of Mining and Technology 18:266-270 doi:http://dx.doi.org/10.1016/S1006-1266(08)600565

[19] Zhu M, Chung DDL (1997) Improving brick-tomortar bond strength by the addition of carbon fibers to the mortar Cement and Concrete Research 27:1829-1839 doi:http://dx.doi.org/10.1016/S00088846(97)00179-8 